\title{
AKTIVITAS SITOTOKSIK EKSTRAK ETANOLIK HERBA CIPLUKAN (Physalis angulata L.) PADA SEL KANKER LEHER RAHIM HeLa MELALUI MODULASI EKSPRESI PROTEIN p53
}

\author{
Andita Pra Darma, Rosana Anna Ashari, Perdana Adhi Nugroho, \\ Ameilinda Monikawati, Ilham Agusta Fauzi, Adam Hermawan dan Edy \\ Meiyanto* \\ Cancer Chemoprevention Research Center \\ Fakultas Farmasi, Universitas Gadjah Mada, Yogyakarta \\ * Korespodensi : \\ Prof. Dr. Edy Meiyanto, Msi., Apt. \\ e-mail: meiyan_e@ugm.ac.id \\ http://ccrc.farmasi.ugm.ac.id

\section{ABSTRAK}

Kanker leher rahim merupakan salah satu penyebab kematian wanita akibat kanker terbesar di negara-negara berkembang. Salah satu strategi penanganan kanker leher rahim yang didasarkan pada penemuan agen-agen sitotoksik kini terus dikembangkan. Ciplukan (Physalis angulata L.) adalah salah satu tanaman yang berpotensi sebagai agen kemopreventive karena kandungan Fisalin dan Withangulatin di dalamnya. Oleh karenanya, penelitian ini bertujuan untuk mengetahui efek ekstrak etanolik herba ciplukan (EHC) terhadap aktivitas sitotoksik sel kanker leher rahim HeLa.

Evaluasi viabilitas sel melalui nilai IC ${ }_{50}$ ditetapkan dengan MTTassay. Ekspresi protein yang berperan dalam regulator proliferasi sel seperti p53 diamati dengan metode imunositokimia. Ekstrak etanolik herba ciplukan menunjukkan efek sitotoksik dengan $I_{50}$ $158 \mu \mathrm{g} / \mathrm{ml}$. Pengamatan lebih lanjut terhadap protein yang berperan dalam regulator proliferasi sel menunjukan bahwa EHC mampu menginduksi ekspresi p53 yang merupakan protein penghambat proses proliferasi sel. Berdasarkan hasil penelitian ini dapat disimpulkan bahwa EHC berpotensi untuk dikembangkan sebagai agen antikanker pada kanker leher rahim.

Kata kunci : Ciplukan (Physalis angulata L.), antiproliferasi, sel HeLa, p53

\begin{abstract}
Cervical cancer is one of leading cause of cancer death in women in the developing countries. One of the strategy to prevent cervical cancer based on cytotoxic agents are now being developed. Ciplukan (Physalis angulata L.) is one of potential plant as chemopreventive agent due to Physalin and Withangulatin constituent in this plant. This study was aimed to know cytotoxic effect of ciplukan ethanolic extract (CEE) in human cervical carcinoma Hela cell line.

Evaluation of cell viability value was determined using MTT assay. The expression of p53 as cell proliferation regulator was observed with immunocytochemistry assay. Ethanolic extract of ciplukan showed cytotoxic effect in HeLa cell line with $I C_{50}$ of $158 \mu \mathrm{g} / \mathrm{ml}$. Further observation of cell proliferation regulator showed that CEE induces expression of p53 that inhibit cell proliferation. The result showed that CEE has potential activity to be developed as anticancer agent in human cervical cancer.
\end{abstract}

Keywords : Ciplukan (Physalis angulata L.), antiproliferation, HeLa cell line, p53 


\section{PENDAHULUAN}

Kanker leher rahim merupakan kanker yang insidensinya cukup tinggi di dunia (1). Kanker leher rahim atau lebih dikenal dengan nama kanker serviks merupakan penyebab kematian terbesar ketiga pada wanita di dunia dan pada negara-negara berkembang kanker ini membunuh wanita lebih banyak dibanding kanker lainnya (2). Lebih dari $83 \%$ kematian tiap tahun terjadi pada negaranegara berkembang di dunia yaitu 68.000 kasus di Afrika, 77.000 kasus di Amerika Latin, dan 245.000 kasus di Asia (2). Berdasarkan kondisi ini, maka pengatasan kanker dengan menghambat dan mematikan pertumbuhan sel kanker secara selektif perlu diupayakan.

Kanker merupakan penyakit yang dicirikan dengan adanya pertumbuhan sel yang tak terkendali, menginvasi ke jaringan sekitarnya dan menyebar (metastasis) ke bagian tubuh yang lain (3). Pada kanker, sel kehilangan fungsi kontrolnya terhadap daur sel maupun fungsi homeostasis, sehingga sel dapat berproliferasi terus menerus dan membentuk jaringan abnormal (4). Pada sel normal, sinyal antiproliferatif bekerja untuk menjaga keteraturan sel dan homeostatis jaringan. Sinyal anti pertumbuhan dapat memblok proliferasi dengan dua mekanisme yang berbeda, yaitu sel dipaksa keluar dari fase proliferasi yang aktif menuju fase istirahat $G_{0}$ atau sel diinduksi untuk melepaskan potensi proliferasi secara permanen untuk memasuki fase post mitotic (5).

Ciplukan (Physalis angulata L.)adalah tumbuhan tahunan yang banyak terdapat pada daerah tropis dan subtropis. Di jawa, tumbuhan ini tumbuh secara liar di kebun, ladang kering, tepi jalan, dan di hutan-hutan (6). Berdasarkan dari penelitian yang sudah ada, ciplukan dapat berfungsi sebagai stimulator sistem imun, memiliki efek sitotoksik pada beberapa tipe sel kanker, dan memiliki aktivitas antiviral (7). Pada penelitian yang lain Physalis angulata memiliki aktivitas antihepatoma pada sel hepatoma manusia Hep G2, Hep 3B dan PLC/PRF/5 (8). Pada penelitian selanjutnya, didapatkan hasil bahwa Physalis angulata berperan dalam regulasi proliferasi, siklus sel dan apoptosis sel kanker payudara MDA-MB 231 (9). Physalis angulata menghentikan sel kanker tersebut pada fase G2/M melalui penurunan level cyclin A / cyclin B, dan meningkatkan level $\mathrm{p} 21^{\text {wafl/cip1 }}, \mathrm{p} 27^{\text {kip } 1}$ dan Chk2 pada fase G2/M dimana terjadi peningkatan fosforilasi Cdc25C (inaktif) dan menginduksi penekanan level Cdc2 serta meningkatkan level Wee1 (9). Data-data yang dikemukakan di atas menunjukkan bahwa ekstrak etanolik ciplukan mempunyai potensi sitotoksik dan antiproliferasi.

Pada penelitian ini akan diuji mengenai potensi sitotoksik ekstrak etanolik Physalis angulata pada sel kanker leher rahim HeLa. Selain itu juga akan diteliti serta kemungkinan mekanisme di dalamnya. Hasil penelitian ini diharapkan dapat menjadi dasar pengembangan Physalis angulata sebagai alternatif pengobatan kanker leher rahim.

\section{BAHAN DAN METODE PENELITIAN}

\section{Tempat dan Waktu Pelaksanaan}

Penelitian ini dilaksanakan di Laboratorium Parasitologi Fakultas Kedokteran dan Laboratorium Cancer Chemoprevention Research Center (CCRC), Fakultas Farmasi Universitas Gadjah Mada pada bulan Januari 2009 Mei 2009.

\section{Alat Penelitian}

Ekstraksi 
Glassware, kain kasa, kertas saring, pengaduk, corong porselin, rotary evaporator (Heidolph WB 2000), pompa vakum (Gast-USA), alat penyaring, dan flakon.

\section{Uji In Vitro}

Alat yang digunakan untuk uji in vitro adalah : autoclave (Hirayama HV-25 020585175, Hirayama Manufacturing Co., Jepang), Labconco purifier class II biosafety cabinet (Delta Series, Labconco Corporation, Missouri, USA), inkubator $\mathrm{CO}_{2}$ (Heraeus), inverted microscope (Carl Zeiss Axiovert 25, Germany), tissue culture flask/dish diameter $10 \mathrm{~cm}$ (Iwaki), 96-well plate (Iwaki), 24-well plate (Iwaki), neraca analitik (Sartorius), mikropipet (Pipetman ${ }^{\mathrm{R}}$ neo Gilson, France), mikroskop cahaya (Nikon YS 100, Japan), yellow tip (Brand), blue tip (Brand), konikal $15 \mathrm{ml}$ steril (Falcon), tissue, alat-alat gelas, coverslip diameter $13 \mathrm{~mm}$ (Thermanox), slide, haemocytometer (Nebauer improved 0,100 $\mathrm{mm}$ Tiefe Depth Profondeur 0,0025 mm², Germany), cell counter, ELISA reader (Bio-Rad microplate reader Benchmark serial no.11565, Jepang), shaker (MRKRETAC),vortex (Maxi Mix II, Thermolyne type 37600 mixer, Iowa, USA), eppendorf steril (Plasti Brand), kamera digital (Canon IXY Digital 25 IS 10,0 mega pixels, Japan).

\section{Bahan Penelitian}

\section{Bahan Utama}

Bahan utama yang digunakan adalah herba ciplukan (Physalis angulata L.), yang diperoleh dari daerah Dusun Meces, Besi, Sleman, Yogyakarta. Setelah itu herba diidentifikasi, dibersihkan dengan air mengalir, dikeringkan, dan diserbuk. Serbuk herba diekstraksi dengan metode maserasi selama 5 hari dengan penyari etanol $70 \%$ (E.Merck, Darmstadt, Germany).

\section{Media Penumbuh Sel}

Bahan yang digunakan adalah DMEM (Dulbecco's Modified Eagle Medium) (Gibco) yang mengandung Foetal Bovine Serum (FBS) 10\% (v/v) (FBS qualified, Gibco, Invitrogen ${ }^{\mathrm{TM}}$ USA) dan penisilin-streptomisin 1\% (v/v) (Gibco, Invitrogen Corporation, Grand Island, NY, 14072, USA). Sel dipanen dari culture dish/ flask menggunakan Tripsin EDTA 0,25 \% (Gibco, Invitrogen, Canada) untuk melepaskan sel.

\section{Uji Sitotoksik dengan MTT Assay}

Untuk uji sitotoksik, diperlukan kultur sel HeLa koleksi Cancer Chemoprevention Research Center (CCRC) Fakultas Farmasi UGM yang diperoleh dari Prof. Tatsuo Takeya (Nara Institute of Science and Technology (NAIST), Jepang) dengan media kultur DMEM (Dulbecco's Modified Eagle Medium) (Gibco), Reagen MTT \{3-(4,5dimetiltiazol-2-il)-2,5-difenil tetrazolium bromida\} dengan stok $5 \mathrm{mg} / \mathrm{ml}$ dalam phosphate buffer saline (Pereaksi kerja dibuat dengan mengencerkan pereaksi stok 10 kali dengan medium DMEM), pelarut sampel DMSO (Dimetil Sulfoxide) (Sigma Aldrich Chemie GmBH, Steinheim, Germany), Pereaksi stopper yang mengandung natrium dodesil sulfat (SDS, Merck-Schuchardt, Dr.Th.Schuchardt \& Co, D-85662 Hobenbrunn, Germay) 10\% dalam 0,1 N HCl (Merck, Darmstadt, Germany), dan larutan pencuci Phosphate Buffer Saline (PBS) pH 7,4 yang dibuat dengan melarutkan $0,2 \mathrm{~g} \mathrm{KCl}$ (for molecular biology, murni HPLC e" 99,0\% No Katalog 7447-40-7, Sigma Aldrich Chemie GmBH, Steinheim, Germany); $8 \mathrm{~g}$ $\mathrm{NaCl}$ (for molecular biology, murni HPLC e" 98\% No Katalog 7647-14-5, Sigma Aldrich Chemie GmBH, Steinheim, Germany); $1,15 \mathrm{~g} \mathrm{Na}_{2} \mathrm{HPO}_{4}$ (for molecular biology, murni HPLC e" 98,5\% No Katalog 
7558-79-4, Sigma Aldrich Chemie GmBH, Steinheim, Germany); 0,2 g KH$_{2} \mathrm{PO}_{4}$ (for molecular biology, murni HPLC e" $98 \%$ No Katalog 7778-77-0, Sigma Aldrich Chemie GmBH, Steinheim, Germany) dalam 1 liter aquades.

\section{Imunositokimia}

Dalam uji imunositokimia, diperlukan metanol (E.Merck, Darmstadt, Germany), mouse monoclonal anti-human p53 (Novocastra, Leica Biosystems Newcastle), universal detection kit (streptavidin-HRP, antibodi sekunder terbiotinilasi, serum kuda/ blocking serum, kromogen 3,3-diaminobenzidin (DAB)) (Ultravision plus detection system, Ref TP 125-HLX, Runcorn, Cheshire, WA71PR, UK; Novostain Universal Detection kit NCL-RTU, Novocastra Lab Ltd., Newcastle NE12 8EW, UK), Phosphate Buffer Saline, aquades, xilol, lem (mounting media), dan mayer-hematoksilin (Dako).

\section{Prosedur Penelitian}

Uji Sitotoksisitas

Uji sitotoksisitas menggunakan metode MTT [3-4, 5-dimetiltiazol-2-il)-2,5difeniltetrazolium bromida] (Mosmann, 1983). Langkah kerja dimulai dengan mengambil sel dari inkubator $\mathrm{CO}_{2}$, kemudian amati keadaan sel. Kultur sel yang digunakan dalam kondisi $80 \%$ konfluen untuk dipanen. Langkah selanjutnya, sel dipanen dan dihitung jumlahnya, lalu membuat pengenceran sel dengan media kultur lengkap (MK) sesuai kebutuhan. Kemudian sel ditransfer ke dalam 96-well plate dengan jumlah $5 \times 10^{3}$ sel/ sumuran dilanjutkan dengan menginkubasi sel selama semalam. Setelah itu, ke dalam sumuran ditambahkan sampel dengan berbagai konsentrasi dengan kosolven DMSO dan diinkubasi pada suhu $37^{\circ} \mathrm{C}$ dalam inkubator $\mathrm{CO}_{2} 5 \%$ selama 24 jam. Setelah inkubasi berakhir ditambahkan
$100 \mu 1$ reagen MTT konsentrasi $(0,5 \mathrm{mg} /$ ml) dalam DMEM ke dalam setiap sumuran. Kemudian diinkubasi pada suhu $37^{\circ} \mathrm{C}$ kembali selama 3 jam sampai terbentuk formazan. Lalu dilakukan pengamatan kondisi sel dengan mikroskop inverted. Jika formazan telah jelas terbentuk, ditambahkan stopper SDS $10 \%$ dalam $0,1 \mathrm{~N} \mathrm{HCl}$. Setelah itu, plate kembali dibungkus dengan kertas atau alumunium foil dan diinkubasi di tempat gelap selama semalam. Serapan dibaca dengan ELISA reader pada $\lambda 595 \mathrm{~nm}$.

\section{Pengamatan Ekspresi Protein dengan} Imunositokimia

Kultur sel HeLa sebanyak $5 \times 10^{4}$ sel/ sumuran ditransfer ke dalam 24-well plate yang telah diisi dengan cover slip kemudian sel diinkubasi semalam pada suhu $37^{\circ} \mathrm{C}$ dalam inkubator $\mathrm{CO}_{2} 5 \%$. Setelah sel pulih kembali, diberi perlakuan ekstrak dan diinkubasi kembali selama 15 jam. Pada akhir waktu inkubasi, sel dicuci PBS kemudian ditambahkan metanol dingin dan diinkubasi di dalam freezer $-4^{\circ} \mathrm{C}$ selama 10 menit. Sel yang telah difiksasi kemudian dicuci dengan aquades 2 kali kemudian diinkubasi dalam larutan hidrogen peroksidase selama 10 menit. Selanjutnya, sel ditetesi dengan prediluted blocking serum dan diinkubasi 10 menit. Kemudian ditetesi dengan Antibodi Monoklonal primer anti p53 (pengenceran 1:50), diinkubasi selama 10 menit, dan dicuci dalam PBS sebanyak 3 kali. Preparat diinkubasi dalam biotin selama 10 menit dan dicuci dengan PBS sebanyak 2 kali selama 5 menit. Setelah dicuci dengan PBS, sel ditetesi dengan antibodi sekunder (biotinylated universal secondary antibody) dan diinkubasi kembali selama 10 menit. Kemudian preparat diinkubasi dalam streptavidin-peroksidase selama 10 menit dan dicuci dengan PBS sebanyak 2 kali selama 5 menit. Selanjutnya, preparat dicuci 
kembali dengan PBS lalu diinkubasi dalam DAB selama 10 menit dan dicuci dengan aquades. Preparat kemudian direndam dalam larutan Mayer-Haematoxylin selama 3-4 menit untuk counterstain dan dicuci dengan aquades. Cover slip kemudian diangkat dandicelupkan ke dalam xylol, kemudian dicelupkan ke dalam alkohol. Setelah kering, cover slip diletakkan di atas kaca obyek dan ditetesi dengan lem (mounting media). Cover slip ditutup dengan slide kemudian dilakukan pengamatan dengan mikroskop cahaya.

\section{Analisis Hasil}

\section{Uji Sitotoksisitas}

Data yang didapat dari ELISA

Reader berupa hasil absorbansi masing masing sumuran dikonversikan dalam persen kehidupan sel. Persen kehidupan sel dihitung dengan menggunakan persamaan :

$\%$ sel hidup $=[($ absorbansi sel dengan perlakuan -absorbansi kontrol media)/ (absorbansi kontrol sel-absorbansi kontrol media)]x $100 \%$

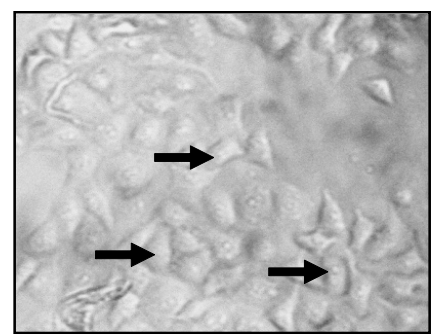

(A)

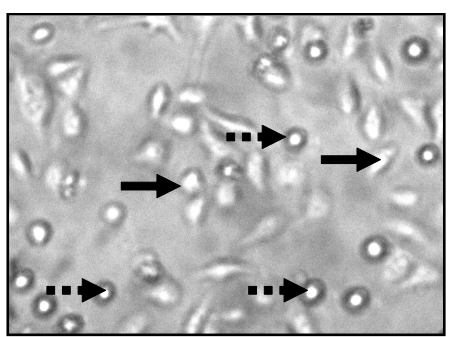

(B)

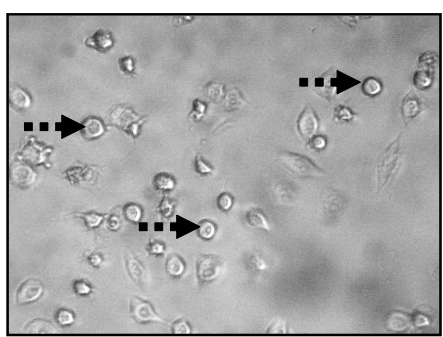

(C)

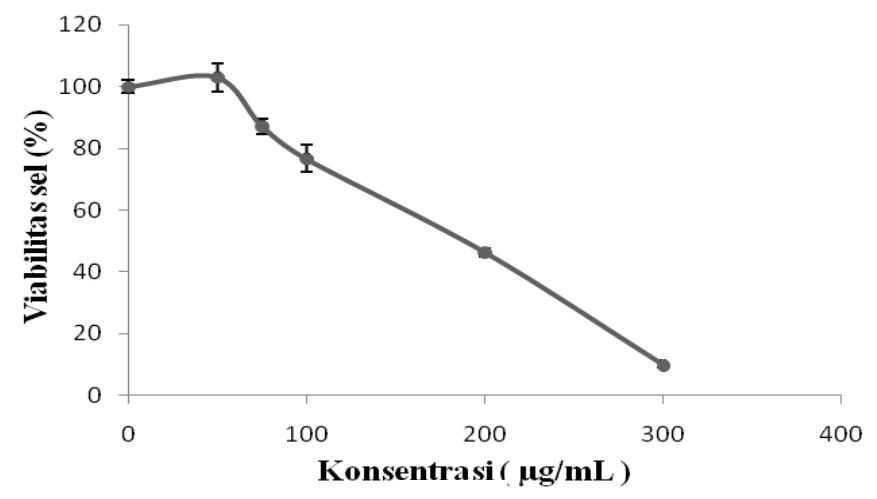

(D)

Gambar 1. Efek Perlakuan Ekstrak Etanolik Herba Ciplukan (EHC) terhadap Viabilitas Sel HeLa. Sel HeLa dengan kepadatan $\left(5 \times 10^{3}\right)$ diberi perlakuan ekstrak $(50-300 \mu \mathrm{g} / \mathrm{mL})$ dan diinkubasi selama 24 jam. Viabilitas sel didapat dari konversi nilai absorbansi formazan yang terbentuk akibat perlakuan MTT seperti yang dijelaskan pada prosedur penelitian. Dibandingkan pada kontrol sel (A), pada perlakuan konsentrasi $100 \mu \mathrm{g} / \mathrm{mL}$ (B) dan $200 \mu \mathrm{g} /$ $\mathrm{mL}(\mathrm{C})$ terjadi perubahan populasi dan morfologi sel. Perlakuan ekstrak etanolik herba ciplukan menurunkan viabilitas sel secara dose dependent (D). Profil viabilitas sel disajikan dari rata-rata \pm standard error (SE) dari 3 eksperimen. Ekstrak memiliki efek sitotoksik terhadap sel HeLa dengan nilai $\mathrm{IC}_{50}$ sebesar $158 \mu \mathrm{g} / \mathrm{ml}$ yang didapat dari perhitungan regresi linear log kadar vs viabilitas sel. Tanda panah menunjukkan bentuk morfologi sel HeLa. Pengamatan morfologi sel dilakukan pada jam ke-24 menggunakan inverted microscope dengan perbesaran mikroskop 100x. Keterangan: Sel HeLa normal, Sel yang telah mengalami perubahan morfologi. 
Kemudian dihitung konsentrasi $\mathrm{IC}_{50}$ yaitu konsentrasi yang menyebabkan kematian 50\% populasi sel sehingga dapat diketahui potensi sitotoksisitasnya (10). Perhitungan nilai $\mathrm{IC}_{50}$ didapat dengan menggunakan regresi linear log kadar vs viabilitas sel.

\section{Pengamatan Ekspresi Protein}

Hasil Pengamatan imunositokimia menggunakan antibodi monoklonal primer anti p53dengan substrat DAB dikatakan positif adanya protein $\mathrm{p} 53$ apabila pada inti sel dihasilkan warna coklat/gelap, sedangkan bila pada inti sel setelah fiksasi dengan Hematoksilin dihasilkan warna ungu, maka menunjukkan hasil negatif adanya protein $\mathrm{p} 53$.

\section{HASIL DAN PEMBAHASAN}

\section{Uji Sitotoksik Ekstrak Etanolik Herba Ciplukan terhadap Sel HeLa}

Komponen aktif dalam ciplukan yang berperan sebagai agen antikanker adalah fisalin dan withangulatin. Fisalin dan withangulatin merupakan suatu secosteroid yang banyak ditemukan dalam herba, terutama pada batang dan daun (11). Uji sitotoksik dilakukan untuk mengetahui potensi ketoksikan dari bahan uji yang berupa ekstrak etanolik herba ciplukan (EHC) yang dinyatakan dalam parameter IC50.

Proses evaluasi dari viabilitas sel digunakan metode MTT assay. Metode MTT dengan substrat 3-(4,5-dimetiltiazol2-il)-2,5-difenil tetrazolium bromida digunakan untuk mengevaluasi sel yang hidup berdasarkan aktivitas enzim yang dapat diukur secara kolorimetri (12). Hasil yang didapat adalah EHC dengan konsentrasi $100 \mu \mathrm{g} / \mathrm{ml}$ (gambar 1B) mengubah morfologi sel HeLa dibandingkan dengan kontrol sel (gambar 1A). Hal ini juga terlihat pada konsentrasi $200 \mu \mathrm{g} / \mathrm{ml}$ (gambar 1C) dimana semakin banyak sel HeLa yang mengalami perubahan morfologi. Perubahan morfologi ini menggambarkan kematian sel walaupun belum bisa dipastikan sel tersebut mengalami nekrosis atau apoptosis.

Berdasarkan morfologi dan viabilitas sel, perlakuan tunggal EHC dengan seri kadar $50 \mu \mathrm{g} / \mathrm{ml}, 75 \mu \mathrm{g} / \mathrm{ml}, 100$ $\mu \mathrm{g} / \mathrm{ml}, 200 \mu \mathrm{g} / \mathrm{ml}$, dan $300 \mu \mathrm{g} / \mathrm{ml}$ menunjukkan adanya korelasi antara konsentrasi larutan uji dengan efek toksik yang ditimbulkan. Grafik hubungan

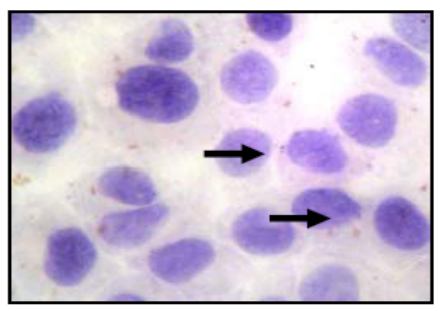

(A)

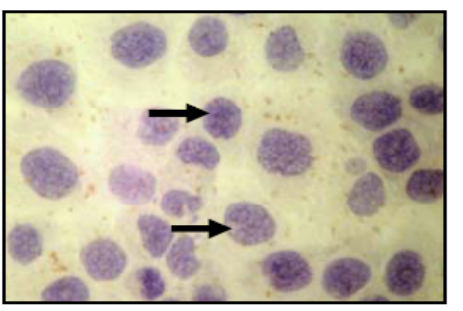

(B)

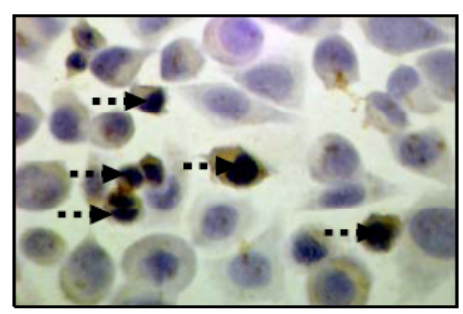

(C)

Gambar 2. Efek Perlakuan Ekstrak Etanolik Herba Ciplukan (EHC) terhadap Ekspresi Protein p53 pada Sel HeLa. Sel HeLa dengan kepadatan $\left(5 \times 10^{4}\right)$ diinkubasi pada coverslips dalam 24 well plate selama 24 jam untuk beradaptasi, lalu diberi perlakuan ekstrak (200 $\mu \mathrm{g} / \mathrm{mL}$ ), diinkubasi kembali selama 15 jam dan dilakukan pengecatan p53 dengan menggunakan metode imunositokimia sesuai prosedur penelitian. (A) Kontrol Sel, (B) Sel tanpa antibodi anti p53, (C) Sel dengan ekstrak konsentrasi $200 \mu \mathrm{g} / \mathrm{mL}$ dengan antibodi anti p53 menunjukkan peningkatan ekspresi protein p53 terlihat dari inti sel yang berwarna coklat tua. Tanda panah menunjukkan ekspresi protein p53. Mikroskop yang digunakan adalah mikroskop cahaya dengan perbesaran 400x. Keterangan : Ekspresi positif, ekspresi negatif. 
konsentrasi dan viabilitas sel (gambar 1D) menunjukaan bahwa semakin tinggi konsentrasi akan mengurangi viabilitas sel. Hasil yang diperoleh menunjukkan fenomena dose dependent, efek toksik meningkat seiring peningkatan konsentrasi, yang berarti semakin kecil jumlah sel yang hidup. Harga $\mathrm{IC}_{50}$ perlakuan EHC terhadap sel HeLa yang diperoleh adalah $158 \mu \mathrm{g} / \mathrm{ml}$.

\section{Pengamatan Ekspresi Protein p53}

Untuk mengetahui mekanisme yang memerantarai EHC dalam menghambat pertumbuhan sel HeLa dilakukan metode imunositokimia berdasarkan ikatan antibodi spesifik. Proses kematian sel ada beberapa kemungkinan yang memerantarainya, salah satunya adalah mekanisme antiproliferatif yang menghambat pembelahan sel kanker. Salah satu regulator proliferasi yang berperan dalam sel adalah protein p53. Untuk itu dilakukan penelusuran mekanisme dari EHC terhadap ekspresi protein p53.

Hasil pengamatan ekspresi protein p53 pada sel HeLa akibat perlakuan EHC memperlihatkan adanya perbedaan warna dibandingkan sel tanpa perlakuan (Gambar 2. Pada kontrol sel / sel HeLa normal, protein $\mathrm{p} 53$ tidak terekspresi (Gambar 2A) dimana sel berwarna ungu seperti pada kontrol sel tanpa antibodi anti p53 (Gambar 2B). Protein p53 terekspresi pada inti sel, sehingga inti sel yang mengalami ekspresi p53 akan berwarna coklat (Gambar 2C).

\section{Pembahasan}

Pada penelitian ini akan diuji mengenai potensi sitotoksik EHC pada sel kanker leher rahim HeLa serta kemungkinan mekanisme di dalamnya. Uji sitotoksik EHC mampu menghambat pertumbuhan sel. Penghambatan pertumbuhan sel dapat terjadi melalui berbagai mekanisme, salah satunya adalah mekanisme regulasi siklus sel. Hal inilah yang dapat kami asumsikan adanya mekanisme penghambatan proliferasi sel.

Pada perlakuan tunggal EHC terhadap sel HeLa menunjukkan efek toksik yang dapat terlihat dari perubahan morfologi sel. Ekstrak dengan seri kadar 50 $\mu \mathrm{g} / \mathrm{ml}, 75 \mu \mathrm{g} / \mathrm{ml}, 100 \mu \mathrm{g} / \mathrm{ml}, 200 \mu \mathrm{g} / \mathrm{ml}$, dan $300 \mu \mathrm{g} / \mathrm{ml}$ menunjukkan adanya fenomena dose dependent dimana ada korelasi antara konsentrasi larutan uji dengan efek toksik yang ditimbulkan. Hasil yang diperoleh menunjukkan bahwa efek toksik meningkat seiring peningkatan konsentrasi, yang berarti semakin kecil jumlah sel yang hidup. Harga $\mathrm{IC}_{50}$ perlakuan EHC terhadap sel HeLa yang diperoleh pada penelitian ini adalah $158 \mu \mathrm{g} / \mathrm{ml}$. Nilai $\mathrm{IC}_{50}$ kurang dari $100 \mu \mathrm{g} / \mathrm{ml}$ merupakan

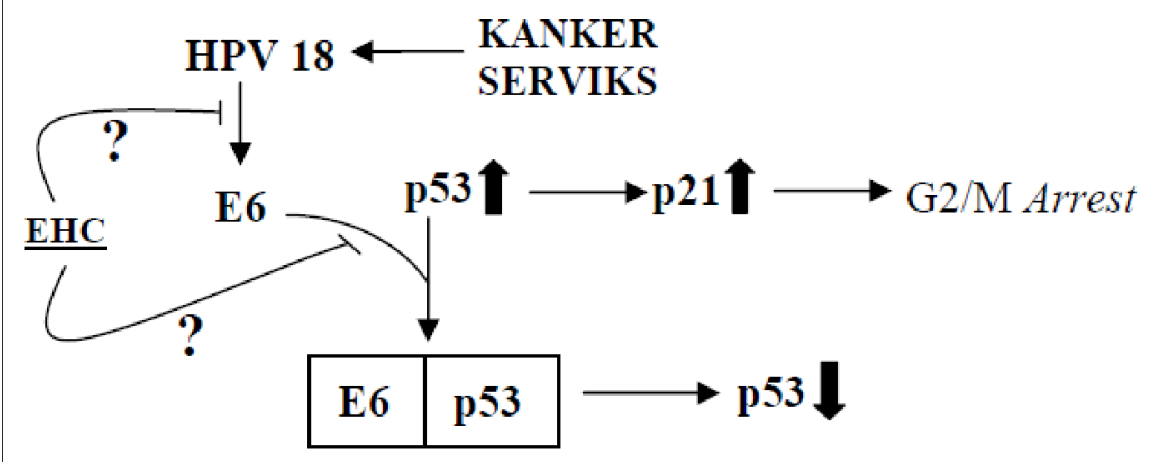

Gambar 3. Kemungkinan Mekanisme EHC dalam Penghambatan Proliferasi Sel HeLa. Ekstrak Etanolik Herba Ciplukan (EHC) menghambat pembentukan E6 (down regulation), menghambat ikatan E6 dan p53 sehingga mengakibatkan ekspresi p53 meningkat. Protein p53 akan menginduksi p21 yang akhirnya menyebabkan G2/M Arrest (proliferasi sel berhenti). 
agen antikanker poten sedangkan nilai $\mathrm{IC}_{50}$ di atas $100 \mu \mathrm{g} / \mathrm{ml}$ merupakan agen kemopreventif yang poten (13). Berdasarkan nilai $\mathrm{IC}_{50}$ yang diperoleh, $\mathrm{EHC}$ berpotensi dikembangkan sebagai agen kemopreventif yang potensial.

Selain melihat efek sitotoksik dari EHC, penelitian ini juga mengkaji mekanisme yang terkait di dalamnya. Salah satu kemungkinan mekanisme yang terkait dengan penghambatan pertumbuhan sel adalah melalui regulasi siklus sel. Untuk itu dilihat ekspresi protein p53 yang mana diduga penting dalam regulasi siklus sel dengan menggunakan metode imunositokimia.

Protein p53 merupakan kunci regulator dalam proses seluler yang meliputi cell cycle control, kematian sel yang terprogram, perbaikan DNA, stabilitas genom, dan diferensiasi (14). Protein p53 ini juga faktor transkripsi yang mengaktivasi transkripsi dari berbagai macam gen seluler seperti $p 21^{\text {Wafl }}$, bax, cylin $G$, dan Mdm2 (15). Pada kanker serviks, p53 mengalami penurunan fungsi karena protein E6 yang dihasilkan oleh HPV akan mengikat p53, kemudian mendegradasinya (16). Untuk itulah pada hasil imunositokimia untuk kontrol sel (gambar 2A), protein p53 tidak terekspresi. Pada perlakuan EHC konsentrasi $200 \mu \mathrm{g} / \mathrm{ml}$ terlihat adanya peningkatan ekspresi protein p53 (gambar 2C). Kami menduga peningkatan ekspresi protein p53 inilah yang menyebabkan kematian sel HeLa, yaitu melalui mekanisme antiproliferatif.

Ada dua kemungkinan yang memerantarai induksi ekspresi protein p53 oleh EHC. Kemungkinan yang pertama berkaitan dengan adanya mekanisme down regulation dari E6 walaupun pada penelitian ini tidak melihat level E6 secara seluler.

Mekanisme down regulation dari E6 ini kemungkinan akibat adanya inhibisi ciplukan dalam proses transkripsi dari E6.
Hal ini akan menyebabkan peningkatan level p53 karena proses degradasi p53 oleh E6 tidak terjadi. Kemungkinan yang kedua adalah EHC menghambat terjadinya ikatan E6 dengan protein $\mathrm{p} 53$ yang mengakibatkan proses degradasi protein $\mathrm{p} 53$ menurun atau bahkan tidak terjadi. Kami menyarankan untuk dilakukan penelitian lebih lanjut untuk melihat level dari E6 secara seluler sehingga dapat dilihat mekanisme hubungan E6 dengan peningkatan protein $\mathrm{p} 53$.

Peningkatan ekspresi protein p53 akan menyebabkan terhentinya proses proliferasi sel. Protein p53 dapat menyebabkan transkripsi beberapa protein yang berperan dalam kontrol siklus sel, salah satunya adalah $\mathrm{p} 21^{\text {wafl/cipl }}$ (17). Protein p2 $1^{\text {wafl/cip } 1}$ merupakan mediator dari p53 untuk menginduksi growth arrest pada fase G2/M (18), menghambat CDK, dan menghentikan siklus sel sehingga mencegah replikasi DNA yang rusak (19). Pada penelitian terdahulu, ciplukan menaikkan level p2 $1^{\text {wafl/cipl }}$ pada sel kanker payudara MDA-MB 231 (9), untuk itu diperkirakan terjadi juga pada sel HeLa. Kemungkinan jalur yang terjadi adalah peningkatan ekspresi p53 menyebabkan terjadi peningkatan ekspresi p21 (downstream dari p53). Ekspresi protein p21 inilah yang kami asumsikan menjadi penyebab proliferasi sel kanker tersebut berhenti pada pada fase $\mathrm{G} 2$ / M (growth arrest). Perlu penelitian lebih lanjut mengenai ekspresi protein p21 maupun protein-protein lain yang merupakan downstream dari p53. Selain itu juga perlu dilakukan penelitian yang mengkaji mengenai siklus sel dengan metode flowcytometri untuk menjelaskan mekanisme tersebut.

Berbagai mekanisme tersebut mampu menjelaskan aksi molekuler yang memperantarai potensi sitotoksik EHC pada sel kanker leher rahim HeLa (gambar 3). Dari data - data tersebut semakin meyakinkan bahwa EHC berpotensi sebagai 
agen kemopreventif potensial pada sel kanker leher rahim. Perlu dilakukan penelitian lebih lanjut tentang aplikasi EHC dengan agen kemoterapi sehingga diperoleh kombinasi yang tepat untuk penanganan kanker leher rahim untuk menambah datadata mengenai pemanfaatan tumbuhan ini. Keberhasilan dari penelitian ini diharapkan dapat menghasilkan suatu alternatif pengobatan yang lebih murah dengan memanfaatkan tumbuhan liar di sekitar kita, bahkan di masa mendatang dapat menjadi fitofarmaka yang potensial dalam menunjang pengobatan kanker leher rahim.

\section{KESIMPULAN}

Hasil penelitian yang telah kami lakukan menunjukkan bahwa ekstrak etanolik herba ciplukan (Physalis angulata L.) memiliki efek sitotoksik terhadap sel HeLa dengan IC $_{50} 158 \mu \mathrm{g} / \mathrm{ml}$ dan menginduksi ekspresi protein p53 sebagai regulator proliferasi sel.

\section{UCAPAN TERIMA KASIH}

Ucapan terima kasih disampaikan oleh penulis kepada DP2M - DIKTI melalui Program Kreativitas Mahasiswa 2009 yang telah mendanai penelitian ini.

\section{DAFTAR PUSTAKA}

Yang X, Hao Y, Fereczy A, Tang S, and Pater, A. Overexpression of AntiApoptotic gene BAG-1 in Human Cervical Cancer. Exp Cell Res. 1999;247:200-7.

Garcia M, Jemal A, Ward EM, Center MM, Hao Y, Siegel RL, and Thun, MJ. Global Cancer Facts \& Figures 2007. Atlanta, GA: American Cancer Society; 2007.
King RJB. Cancer Biology, Second Ed. London: Pearson Education Limited; 2000.

Lodish H, Berk A, Zipursky, Lawrence S, Matsurada $\mathrm{P}$, Baltimore $\mathrm{D}$, and Darnel J. Molecular Cell Biology, Fourth Ed., 1054-1082. New York: W.H. Freeman and Company; 2000.

Meiyanto E. Biologi Molekuler, Buku Ajar. Yogyakarta: Proyek QUE Fakultas Farmasi, Universitas Gadjah Mada; 2002.

Steenis CGGJV. Flora Voor de Scholen in Indonesie, diterjemahkan oleh Sorjowinoto, M., edisi ke-6. Jakarta: PT Pradnya Paramitha; 1975.

Pietro RC, Kashima S, Sato DN, Januario $\mathrm{AH}$, and Franca SC. In vitro Antimycobacterial Activities of Physalis angulata L. Phytomedicine. 2000;7(4), 335-338.

Wu, SJ, Ng LT, Chen CH, Lin DL, Wang SS, and Lin CC. Antihepatoma Activity of Physalis angulata and $P$. peruviana Extracts and Their Effects on Apoptosis in Human Hep G2 Cells. Life Sci. 2004;74(16):2061-73.

Hsieh WT, Huang KY, Lin HY, and Chung JG. Physalis angulata induced G2/M phase arrest in human breast cancer cells. Food Chem. Toxicol. 2006; 44:974-983.

Doyle A and Griffiths, J.B. Cell and Tissue Culture for Medical Research. New York: John Willey and Sons Ltd; 2000.

Garcia C, Ribeiro T, and Azambuja. Trypanosoma Rangeli: Effects of Physalin B on The Immune Reactions of The Infected Larvae of Rhodnius prolixus. Exp Parasitol. 2005;112(1):37-43.

Mosmann T. Rapid Colorimetric Assay for Cellular Growth \& Survival: Application to Proliferation \& Cytotoxicity Assays. Journal of 
Immunological Method.1983;

65:65-59.

Ueda JY, Tezuka Y, Banskota AH, Tran

QL, Tran QK, Harimaya Y, Saiki I, and Kadota, S.Antiproliferative

Activity of Vietnamese Medicinal

Plants. Biol. Pharm. Bull.

2002;25(6): 753-760.

May P and May E. Twenty Years of p53

Research: Structural and Functional

Aspects of the p53 Protein.

Oncogene. 1999;18:7621-7636.

Okomato K and Beach D. Cyclin G is a

Transcriptional Target of the p53

Tumor Suppressor Protein. EMBO

J. 1994;13: 4816-4822.

Lane DP. p53, Guardian of The Genome.

Nature. 1992;358:15-16

Vogelstein B, Lane D and Levine AJ.

Surfing the p53 Network. Nature.

2000;408: 307

El-Deiry WS, Tokino T, Waldman T,

Oliner JD, Veleculscu VE, Burrel

M, Hill DE, Healy E, Rees JL,

Hamilton SR, Kinzler KW and

Vogelstein B. Topoligical Control of

p21 (WAF1/CIP1) Expression in

Normal and Neoplastic Tissues.

Cancer Res. 1995;55: 2910

Ko LJ and Prives C.p53 : Puzzle and

Paradigm. Genes Dev.

1996;10:1054 